\title{
岐阜県揖斐川町『旧桂川用水路』整備による経済勃果 ーパラメトリック推計法とノンパラメトリック推計法による評価一
}

高橋 義文（北海道大学大学院）

佐藤 和夫（北海道大学大学院）

\section{1。背景と目的}

近年、農村空間の持つ多面的機能の重要性が注目さ れ始め、各地で農村空間の持つアメニティ特性を生か した地域整備が行われている。こういった整備事業は 公共事業として行われるため、何らかの形で事業効果 を把握する必要がある。だが、この種の整備事業によ る便益には市場を通じた価格付けが行われることはな い。そこで、便益の大きさを金額として評価するため にCVM (Contingent Valuation Method)によ る事業効果算定の試みが行われており、試案段階では あるが「水環境整備の効果算定マニュアル（案）」（農 村環境整備センター－６］）も提供されている1)。こ のことは CVM が研究者だけでなく、学術的な知識 のあまりない実務者によっても実施されることが増え ることを意味している。本報告では岐阜県揖斐川町の 「旧桂川用水路」の整備を対象とした CVM 調查の事 例分析を通じて、効果算定上の実務的な問題点につい て考察を行う。

\section{2. 対象地域と旧桂川用水路の概要}

(1) 対象地域の概要

対象地域となる岐阜県揖斐川町は、岥阜県の西南部 に位置する平場の農村地域である。産業構造の中心は、 第一次産業（主に水田農業）加第三次産業に移行し つつあり、現在は第三次産業の粗生産額が全産業の約 50 \%を占めている、このことに対応して農用地面積 は減少しており、一方で車で 30 分ほどの距離にある 岐皁市・大垣市のベッドタウン化が進むなど、都市化・ 混住化が進行している。1997 年には 3,134 haが都市 計画区域に指定された。人口は 19,000 人台で大きな 上下はないが、世帯数は増加している。

（2）旧桂川用水路の概要

揖斐川町を流れる「旧桂川用水路」は昭和 18 年に 土地改良事業により整備され、爾来農業用水を供給し、 本町の農業発展を支えてきた。老朽化による機能低下 から補修工事が必要となった際に、まず地域行動推進 事業（ふるさと景観作り事業）による親水性を重視し た整備が行われ（昭和 $61 \sim 63$ 年）、さらに平成 6 年
〜 11 年にかけて、水環境整備事業によって未整備区 間の整備が行われた。

現在の旧桂川用水路は、「せせらぎの里」「さくらの 里」「ほたるの里」「歷史の里」の特徵あるテーマパー クを併設しており、近隣住民からあ農村公園として認 識されている。用水路自体に親水性を重視した近自然 河川工法を実施しており、用水路沿線にはあずま屋、 パーゴラ、フットライト、木材チップの遊歩道などの 付帯施設が整備されている。整備完了後は、蛍祭りな どのイベントにも利用されている。

\section{3. 調查概要}

(1) アンケート方法

アンケート調査は平成 12 年 11 月に実施した。アン ケート対象者は、配布・回収とも郵送とし、評洒対象 財である「旧桂川用水路」から半径約 $2 \mathrm{~km}$ 以内にある 8 地区内から NTT の電話帳に載っている全世帯 1,959 世帯に対して送付した。ただし 71 通が未着で あったため、実配布数は 1,888 通である。回収数は 683 通であり、回収率は $36.2 \%$ となった。

(2) 質問形式・支払い形態

CVM の質問部分を図 1 に示した。CVM の形式は 二段階二肢選択形式を採用した。図中の「年間 $* * *$ 円」の部分には500 円から 10,000 円までの第一提示 額（6 種類）が入る。支払い形態は「費用負担」とい う言葉を用い、CVM の質問部分の最後に抵抗回答に 対する質問項目を加えた。また、評価の対象となる整 備が明確になるように、Visual Aide として「旧桂 川用水路」の整備前・整備後の比較写真のパンフレッ トを同封した。

\section{4. 計測}

(1) 計測方法

計測は二段階二肢選択形式のデータ分析で最も一般 的な Hanemann [3]によるパラメトリック推計法 と、前述の効果算定マニュアルで推奨されている、寺 脇［8］によるノンパラメトリック推計法を用いた。 パラメトリック推計法は、支払行動関数を推計するこ 
旧桂川用水路は、農業用水として利用されてきましたが、 老朽化のために改修されました。

以前のような用水路のままの改修も可能でしたが、用水 路のあつ水辺空間を最大限に活用するため、地域景観など に配慮した用水路へと改修しました。

現在の旧桂川用水路は 4 つのゾーン（「ホタルの里」「さ くらの里」「歴史の里」「せせらぎの里」）で構成されてお り、「地元のいび石を使用した護岸整備」「水車」「林橋小 「あずま屋・パーゴラ」、「親水テラス」など従来の用水路 整備にはない多くの施設をも整備しました。

その結果、周辺住民は「散策」や「集いの場」「ホタル などの自然を感じる場」など多くの活動目的でこれらの施 設を利用しています。

そこで、今まで利用してきた旧桂川用水路の用水路とし ての機能部分は、従来通りの方法で維持・管理されますが、 それ以外の 4 つのゾーンで利用できる周辺施設は、地域住 民の費用負担で維持・管理されることになったという状況 を想定してください。

(この費用負担額は旧桂川用水路の多くの施設を維持する ために使われます。)

屯し、この旧桂川用水路の多くの施設を、いろいろな目 的で今後む利用するためには年間 $* * *$ 円の費用負担が必 要とした場合、あなたの抢宅ではこの費用負担をしてもよ いと思いますか？

ただし、寄付をすると、他の目的に使えるお金が減ると いうことを考えてお答えください。

\section{図 1 CVM 質問文}

とによって提示額以外の変数（所得、年齢、etc）の 影響を分析することができるというメリットを持つが、 計測において分布形の仮定が必要であること、専用ソ フトや統計解析用のパッケージソフトを利用しないと 計測が難しいなどのデメリットがある。一方、ノンパ ラメトリック推計法は、他の変数の影響を分析するこ とはできないが、特定の分布形の仮定が不要であるこ と、計算が非常に容易であることなどのメリットがあ

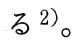

なお、パラメトリック推定法の計測には Econometric Software の Limdep ver7.0を使用 した。また、計測プログラムについては寺脇［9］を 参考とした。

(2) データ

回収された 683 サンプルのうち、CVM の計測に使 用したデータは、CVM の質問部が回答不備だったサ ンプルと抵抗回答サンプルを抜いた 473 サンプル（実 配布数に対する有効回答率 $25.1 \%$ 、以下サンプルセッ トA）を基本に行った。ただし、パラメトリック推 定の際には、必要な項目に回答不備のない 423 サンプ ル（同 $22.4 \%$ 、以下サンプルセットB）を使用した。 両サンプルの諾否反応を表 1 に示す。
表 1 諾否反応

\begin{tabular}{c|c|c|c|c|c}
\hline 初期提示額 & YY & YN & NY & NN & 計 \\
\hline \multirow{2}{*}{500} & 34 & 11 & 8 & 39 & 92 \\
& 32 & 10 & 6 & 36 & 84 \\
\hline \multirow{2}{*}{1000} & 19 & 16 & 13 & 35 & 83 \\
& 18 & 14 & 12 & 31 & 75 \\
\hline \multirow{2}{*}{2000} & 16 & 8 & 14 & 34 & 72 \\
& 14 & 7 & 14 & 30 & 65 \\
\hline \multirow{2}{*}{3000} & 2 & 12 & 16 & 38 & 68 \\
& 2 & 10 & 15 & 34 & 61 \\
\hline \multirow{2}{*}{5000} & 8 & 7 & 16 & 41 & 72 \\
& 8 & 5 & 16 & 32 & 61 \\
\hline \multirow{2}{*}{10000} & 5 & 8 & 19 & 54 & 86 \\
& 5 & 8 & 19 & 45 & 77 \\
\hline \multirow{2}{*}{ 計 } & 84 & 62 & 86 & 241 & 473 \\
& 79 & 54 & 82 & 208 & 423 \\
\hline
\end{tabular}

注）表中の上段はサンプルセット A、段はサンプルセット B の各諾否 反応を表す。

(3) 計測結果（パラメトリック法）

パラメトリック推定にあたっては、正規分布モデル とロジスティック分布モデルを計測し、フィットの良 さからロジスティク分布モデルを採用した。表 2 はパ ラメトリック推計法による支払行動関数の推計結果で ある。採用された変数のうち $10 \%$ 水準で有意となっ たものについて、その含意を概観していこう。まず、 LBID（提示額の対数值）の係数が非常に高い有意性 で負となっていることは、回答者が事業に対する単な る賛否でなく、提示額を十分考慮して回答した結果で あるといえる。また、Lshotoku（所得の対数）の係 数が高い有意性で正となったことは、回答者が各自の 所得制約を考慮して回答したことの証左とみなせる。

Dotozure（今後も『旧桂川用水路』を訪れたい） の係数が高い有意性で正となっていることは、評価額 に利用価値が含まれていることを示している。また、 Dasobiba（『旧桂川用水路』を遊び場として利用） の係数が高い有意性で正となっており、「旧桂川用水 路」を子供の遊び場として利用する回答者が整備事業 に対して特に高いWTPを持っていることを示してい る。

Dsei/siz（『旧桂川用水路』に対して生態系や自然 保護の役に立っていると思う）の係数が高い有意性で 正となったことは、『旧桂川用水路』には魚や源氏ボ タルが生息していることと、近自然河川工法を用いた 用水路であることが評価されていることによると考え られる。Dshourai（『旧桂川用水路』を将来世代に 残したいと思う）の係数む高い有意性で正となってお り、評価に遺贈価値が含まれることを示している。 
表 2 パラメトリック推計法による支払行動関数の計測結果

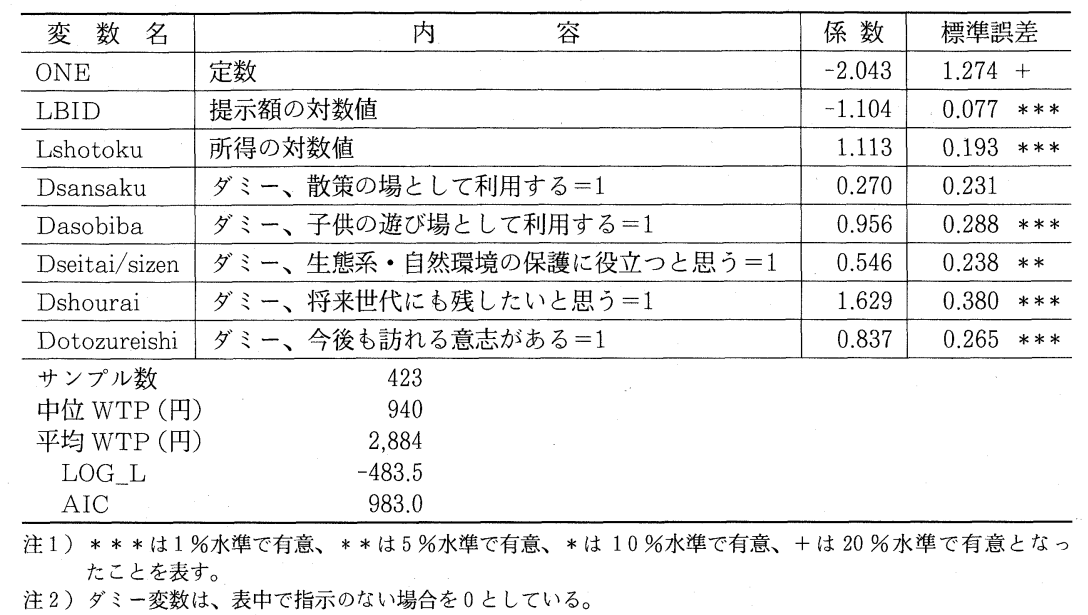

\section{5. 考察}

(1) 総便益の推定

表 3 は今回の CVM 調査から得られた「旧桂川用 水路」の親水整備の効果算定結果である。以下では、 推定 WTP の指標としては、前述の「水環境整備の効 果算定マニュアル（案）」(以下、「効果算定マニュア ル」)で採用されている頭切り平均值について考察を すすめることとする。

表 3 には 3 つのサンプルセットを示した。回収アン ケート総数 (683 通) から、CVM 部の回答不備と抵 抗回答を除いたサンプルセット（473通、サンプルセッ トA）と、パラメトリック推計の検討に用いた独立 变数に回答不備のあったサンプルを除いたサンプルセッ ト（423 通、サンプルセット B)、及び参考としてサ ンプルセット A からサンプルセット B を選ぶ際に除 外したサンプルであるサンプルセット C $(473-423$ = 50 通）である。一般的な手続きに従えば、ノンパ ラメトリック法を採用した場合にはサンプルセット A が、パラメトリック法を採用した場合にはサンプ

\section{表 3 評価額（世帯当り）}

\begin{tabular}{c|c|c|c}
\hline & サンプルセット & サンプルセットB & サンプルセットC \\
\hline サンプル数 & 473 & 423 & 50 \\
\hline $\begin{array}{c}\text { 回収率 (\%) } \\
\begin{array}{c}\text { パラメトリック推計法 } \\
\text { (フルモデル) }\end{array}\end{array}$ & 25.1 & 22.4 & 2.6 \\
\hline $\begin{array}{c}\text { パラメトリック推計法 } \\
\text { (提示額のみのモデル) }\end{array}$ & 3,907 & 2,884 & - \\
\hline ハンパラメトリック推計法 & 4,554 & 4,140 & 2,064 \\
\hline
\end{tabular}

注) 評価額は全て単純頭切り平均。単位は円。
ルセット B が用いられることとなる。この前提では、 ノンパラメトリック推計法による推定 WTP は 4,554 円、パラメトリック推計法による推定 WTP は 2,884 円ということになる。今回の調査において、旧桂川用 水路の受益範囲はおよそ半径 $2 \mathrm{~km}$ 範囲内と設定した。 この範囲内の総世帯数は 1,440 戸であり、これを乗じ て年間の総便益を算出すると、ノンパラメトリック推 計法では約 563 万円、パラメトリック推計法では約 415 万円という結果となる ${ }^{3)}$ 。

(2) 評価額の検討

前節では 2 つ推計値を算出した。この 2 つの推計 値は使用サンプルと推計法の両方が異なっているため、 比較の対象としてはあまり適当ではない。そこでまず、 サンプルセットB を用いたときの両推計法による推 計值（頭切り平均值）を比較すると、ノンパラメトリッ ク推計法による推定 WTP は 4,950 円、パラメトリッ ク推計法による推定WTP は 2,884 円となった。ノン パラメトリック法による推計值はパラメトリック推計 法よりも相対的に大きな推計値（本報告では約 1.7 倍） を与えるという結果である。これは寺脇 [8] や 26 地区の水環境整備事業を対象とした農村環境整備セン 夕ー［7］と同様の傾向である（これは前述のように、 WTP として頭切り平均值を採用した場合である)。 寺脇［8］はこうした推計值の乘離を、パラメトリッ ク推計法の分布形の仮定に誤りがあるためとしている。 しかし、ノンパラメトリック推計法は各提示額での受 諾確率を直線補間しているため、補間の誤差が過大推 計につながっている可能性についても検討が必要だろ う。また、パラメトリック推定法であ、回答者属性を 
含まない提示額のみのモデルによる推計值は 4,140 円 と、フルモデルよりあ大きな值となる。このことは、 所得などの属性情報をモデルに取り这むことによる標 本抽出バイアスの修正が有効であることを示唆してい る。

次に推計法をノンパラメトリック推計法とし、サン プルセット A とサンプルセットBのそれぞれを用い た結果を比較すると、前者は 4,554 円、後者が 4,950 円という結果となる（なお、提示額のみを説明变数と したパラメトリック法で試算すると、前者が 3,907 円、 後者が 4,140 円となる)。この結果は、サンプルセッ 卜AからサンプルセットBを作成する際に除いたサ ンプルの回答者が、対象財に対して相対的に低い WTP しか有していなかったことを示している。試み に、ここで取り除かれたサンプル（サンプルセット C）のみを用いてノンパラメトリック推定法の計測を 行うと、推定 WTP は 1,644 円と極端に小さな值とな る。アンケートにおいて回答不備項目の少ないことが、 対象財に対する関心の強さと関連を持つ可能性は十分 にあると思われる ${ }^{4)}$ 。本報告の場合、サンプルセット $\mathrm{B}$ と C を比較すると、「蛍の里エリアが整備されて良 かったと思う」という項目に「はい」と回答した割合 が前者で $47.5 \%$ 、後者は $36.0 \%$ となるなど、整備事 業の評価に差が表れるほか、「旧桂川用水路」が「以 前は農業用水路であることを知っている」と答えた割 合が前者で $80.9 \%$ 、後者で $66.0 \%$ となるなど、対象 への関心について若干の差が見られる項目があった。 あし、こうした傾向が一般的なのであれば、「アンケー トで所得などを尋ね、回答不備であったときには計測 サンプルから削除する」という手続きは、WTP 推定 において過大推計につながることになる。

「効果算定マニュアル」のように、二段階二肢選択 形式の CVM のデータ分析手法としてノンパラメト リック推計法を（唯一の手法として）採用することは、 このような手続きを踏まずに済むことを含意している。 利用サンプルの絞込みを最小限に済ませることができ るという点は、ノンパラメトリック法のメリットとい えるだろう。特に、事業効果の算定には透明性が求め られるため、手続きは簡素かつ明確であることが望ま しく、この意味でも「効果算定マニュアル」がノンパ ラメトリック法を採用したことは評価できる。だが、 ノンパラメトリック法は、既存研究で多く用いられて いる（フルモデルの）パラメトリック法よりも大きな 推計値を算出する傾向があること、抽出された標本に バイアスがある場合には推計法の中では補正が難しい
こと、という点は認識されなければならない。後者に ついては、サンプルの属性を母集団と比較するなどの 処置も考元られるが、回答不備への本質的な対応には ならない。サンプルの代表性確保のためには、有効回 答率を上げることが重要となる。

現在の事業効果算定の取り組みは試行段階というこ ともあり、前述の「水環境整備事業効果算定マニュア ル」であ、「回答者に所得制約を意識させる」、「サン プル抽出が偏っていないかのチェックに用いる」「調 查の精度向上や手法の簡素化へ向けての研究蓄積」、 という理由から、世帯年収を調查項目に含めるよう定 めている。だが、一般にアンケート調査では、質問量 が少なく回答者の負担が小さいほど、高い回収率を期 待できる（Dillman [2])。特にプライバシーに触 れるような項目は、回収率に与える影響む大きいと考 えられる。この意味で、質問項目を減らすことによる 「アンケート一通あたりの情報量」の減少之、回収率 の向上による「サンプル母集団についての情報量」の 増大はトレードオフの関係を持つため、質問量を減ら すことが、アンケートから得られる情報量全体によ゙う 影響するかは、事前には判断できない。CVM を実務 レベルで用いるようになる際には、詳細なアンケート と簡素なアンケートのどちらが望ましいのか、アンケー ト方法を含めたメ夕分析などによる検討が必要であろ う。

注 1）親水公園整備（旧水環境整備事業）では、2000 年度 新規着工地区から費用便益分析が試行されている（國 光他 $[5])$ 。

2) 二肢選択形式の CVM にノンパラメトリック計測法 を導入した Kriström [4] は、計算について「封筒 の裏でも計算できるほど」容易だ、と表現している。

3）ここでの受益世帯数は役場が今回の受益範囲として認 識している世帯数であり、サンプリングの際の数字と は異なっている。ここでは過大推計を避けるため、小 さな方の数字を採用した。

4）吉田 [11] は農村景観を対象とした CVM のメ夕分 析の中で、回収率が高くなるにつれてWTPが高くな るという結果を報告している。ここでの吉田の意図は 各 CVM 調查間の差異を、対象財の認識や関心を反 映した代理変数としての「回収率」で説明することで あり、本論での議論とは若干文脈が異なるが、アンケー トへの回答意欲とWTP の関連を示すという意味で、 本論の主旨の傍証となろう。

\section{参考文献}

[1]出村克彦・吉田謙太郎編『農村アメニティの創 
造に向けて一農業・農村の公益的機能評価一』、 大明堂、1999。

[2] Dillman, D. A, "Mail and Telephone Surveys: The Total Design Method," John Wiley \& Sons, 1978.

[3] Hanemann, W. M, J. Loomis, B. Kanninen, "Statistical Efficiency of Double-Bounded Dichotomous Choice Contingent Valuation," American Journal of Agricultural Economics, vol.73, pp.1255-1263, 1991.

[4] Kriström, B. , "A Non-Parametric Approach to the Estimation of Welfare Measures in Discrete Response Valuation Studies," Land Economics, Vol.66, pp.135-139, 1990.

[5] 國光洋二 ・松尾芳雄 - 友正達美「農村公園整備 の仮想状況評価額に影響する要因と WTP 関数 移転の可能性一個人属性、整備状況、立地状況 の影響に関してー」、農村計画学会誌』20 巻
1 号、pp.31-39、2001。

[6] 農村環境整備センター「水環境整備の効果算定 マニュアル（案）」、農村環境技術研究 No.56、 2000。

[7]農村環境整備センター「水環境整備事業の CVM 評価検討調査」、農村環境技術研究 No. 56、2000。

[8] 寺脇拓「都市近郊農業の外部経済効果の計測一 二段階二肢選択 CVM におけるノンパラメト リック推定一」、農業経済研究』 69 巻 4 号、 pp.201-212、1998。

［9］寺脇拓「Limdep による二段階二肢選択 CVM の計測」『神戸大学農業経済』33 号、pp.101112、2000。

[10）寺脇拓「農業関連公共事業の便益関数移転」、 『農業経済研究』 71 巻 4 号、pp.179-187、2000。

[11］吉田謙太郎「便益移転による環境評価の収束的 妥当性に関する実証分析 $-メ$ 夕分析と便益関数 移転の適用一」、農業経済研究』 72 巻 3 号、 pp.122-130、2000。 